FACTA UNIVERSITATIS

Series: Philosophy, Sociology, Psychology and History Vol. 19, No 3, 2020, pp. 257 - 273

https://doi.org/10.22190/FUPSPH2003257P

Original Scientific Paper

\title{
FEMALE PUBLIC RELATIONS PROFESSIONALS' PERCEPTIONS ON THE PORTRAYAL OF THE \#METOO MOVEMENT IN CROATIAN MEDIA
}

UDC 305-055.2:316.774(497.5)

\section{Mirela Polić}

Aspira University College, Croatia

\begin{abstract}
The \#MeToo movement gained prominence in 2017 when the \#MeToo hashtag went viral and woke up the world to the magnitude of the problem of sexual violence. It was the actress Alyssa Milano who made the first viral tweet accusing Hollywood producer Harvey Weinstein of sexual assault. Since research on the \#MeToo movement across cultural contexts is limited and mostly comes from Western countries, this research aims to explore the perceptions of six female public relations experts on the portrayal of the \#MeToo movement in Croatian media. Thematic analysis has been conducted to analyse data from six interviews. The results show three main themes in the responses from the interviewees: media's failure to protect the public interest, insufficient visibility of the \#MeToo movement in Croatian media and the lack of expertise in the media.
\end{abstract}

Key words: Croatia, \#MeToo movement, public relations, journalism, sexual discrimination.

\section{INTRODUCTION}

In 2006, the \#MeToo Movement was founded by the survivor and activist Tarana Burke. She wanted to raise awareness of women who had been abused (Starkey et al. 2019). In 2017, the \#MeToo hashtag went viral and woke up the world to the magnitude of the problem of sexual violence. It was the actress Alyssa Milano who made the first viral tweet (Gersen 2017). She accused Hollywood producer Harvey Weinstein of sexual assault and investigations led to his imprisonment. Milano tweeted the phrase in mid-October, telling her followers: "If you've been sexually harassed or assaulted write 'me too' as a reply to this tweet." When she woke up the next day, more than 30,000 people had used \#MeToo. A number of high-profile posts and responses from American celebrities Gwyneth Paltrow,

Received November 1, 2020 / Accepted December 3, 2020

Corresponding author: Mirela Polić

Aspira University College, Domovinskog rata 65, 21000, Split, Croatia

E-mail: mirela.polic@aspira.hr 
Ashley Judd, Jennifer Lawrence, and Uma Thurman, among others, soon followed. After The New York Times and The New Yorker published accusations of sexual harassment and assault against Weinstein, many more women and some men came forward with allegations against others - including actor Kevin Spacey, comedian Louis C.K. and former NBC anchor Matt Lauer (Saad 2018).

What had begun as local grassroots work had become a global movement - seemingly overnight. Within six months, the message reached a global community of survivors. Suddenly there were millions of people from all walks of life saying "me too". In 2017, Time magazine named "The Silence Breakers," representing people who came forward to report sexual misconduct, its Person of the Year (Zacharek, Dockterman and Sweetland Edwards 2017). The \#MeToo hashtag has circulated in 85 countries because of its broad and inclusive appeal, and its ability to cross lines of stratification.

The \#MeToo is fundamentally concerned with the intersection of sex and power and has framed its concerns in terms of justice which has been vividly crystallized in Harvey Weinstein's indictments in June 2018 (Zacharek, Dockterman and Sweetland Edwards 2018). However, despite the big engagement and positive changes that the \#MeToo movement generated, feminists shed a light on some limitations, and the main limitations that this study will focus on is Gill and Orgad's $(2018,8)$ critique according to which "a significant part of the debate regarding the \#MeToo movement 'remains framed in terms 'bad apples' and 'monsters' who did horrible things, not about the monstrous capitalist, patriarchal and sexist system that has produced, sustained and rewarded these 'bad apples' over decades".

The media have a strong impact on how they represent these power relations and when this representation is used to portray topics of public interest such as the \#MeToo movement, there is a sense that masculine habitus still prevails (Bourdieu 2007). Masculine habitus posits "men and masculine principle as the measure of all things" (Bourdieu 2007, 14) and since journalism remains "a male-dominated profession immersed in the masculine culture of deciding what constitutes news" (Topić 2018, 434), even though its role, first and foremost, is to inform and educate (among other things) the citizenry, it is interesting to see how masculine habitus shapes the portrayal of a topic of public interest that deals with female sexual harassment and discrimination.

In addition to that, research on the \#MeToo movement across cultural contexts is limited and mostly comes from Western countries (Starkey et al. 2019). Up to date, there is no research regarding the portrayal of the \#MeToo movement in Croatian media done from the perspective of female public relations professionals, hence this study can serve as a starting point for further research. Moreover, the Croatian social model is still patriarchal (Tomić-Koludrović and Kunac 2000) and during the 1990s, when Croatia was fighting for its independence, "media were active together with dominant cultural politics of retraditionalization in shaping and promoting traditional gender roles and stereotypes" (Kunac and Sarnavka 2006, 18).

Women were under-represented in the media, especially in the news, political, economy and business sections (Vozab and Zember 2016) and mostly appear in lifestyle and entertainment sections and programmes. Albeit progressive policies and the regulation of gender equality in the media were implemented after 2000, research findings showed that the media continued with "this bleak picture, both in traditional and internet-based media" (Vozab and Zember 2016, 75). Hence, this research will address the portrayal of the \#MeToo movement in the Croatian media by the sociological theory of male habitus 
(Bourdieu 2007) according to which the division between genders is deeply embedded into the social order with men and the masculine principle posited as the measure of all things.

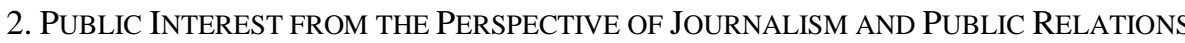

Serving the public interest is not a new concept for journalists and public relations professionals. However, there are challenges in defining which way public interest has to be served from both a journalistic and public relations perspective. The media have a significant role in "helping citizens to make informed choices within democratic, consumer societies" and journalists are often "the representatives of the general public" (Bailey 2009, 300). Journalists report on matters that affect the wider population and that might otherwise go unrecorded (Bailey 2009). There is a belief that journalists are seeking truth in contrast to public relations professionals whose duty is to protect the organisation's interest. Yet, "the simplistic view that journalism is good and PR is bad is hard to sustain" (Bailey 2009, 301).

Public relations has indeed suffered from a poor reputation and image since its earliest professionals paid little attention to ethics or social responsibility (Wright 1979) and professional tools were used to manipulate behaviours rather than serve the public interest (Grunig and Hunt 1984). In addition to that, little research has been done to determine how public relations professionals can serve the public interest (Stoker and Stoker 2012) and one of the reasons is because "much public discussion about public relations focuses only on its ability to harm society" (Halff and Gregory 2015, 719). Critics often state that "all public relations is evil and works against the public good" (Brunner and Smallwood 2019, 3). However, public relations is not good or bad in itself. Public relations can be used for either good or bad purposes (Ihlen and Verhoven 2012) and credible public relations professionals know that public interest is the central tenet in implementing public relations activities.

However, journalists can sometimes be worried that public relations is trying to subside the newsgathering function of the media and sees public relations professionals as "gatekeepers who seek to withhold information, rather than as good sources of news" (Bailey 2009, 301). On the other hand, public relations professionals often see journalists as gatekeepers who have the possibility to decide whether the story will move forward to others in a decision chain. Public interest should be a common agenda on both the journalistic and public relations side. Journalists as neutral intermediaries are standing between public relations professionals and the public (Bailey 2009), whilst public relations professionals are boundary spanners between the organization and external publics (Grunig and Hunt 1984). Both of them should act equally upon striving to fulfil the public interest. Their role is to facilitate the representation of issues of public interest. Public relations professionals "should encourage debate on issues of interest to the public, and, where possible, offer representation when both sides of such issues are not adequately represented so as to foster informed public debate" (Bivins 1993, 125).

Acting as gatekeepers, journalists have the power to select the sources that get a voice in media coverage (van der Meer et al. 2017) and selecting appropriate source can play a crucial role in the coverage of the topic, especially if the topic is of public interest. Due to the disruptive and time-pressuring nature of a crisis, journalists might struggle even more with selecting different sources (Hanitzsch 2004; Veil 2012). Public relations professionals are one of the sources journalists use when covering a story and where a public relations source is credible, there should be less suspicion in the relationship with journalists 
(Bailey 2009), especially if the topic is of public interest. In addition to that, credible PR practitioners become acculturated into the journalists' inner circle of 'contacts' and 'trusted sources'.

\section{GENDERED NATURE OF JOURNALISM AND PUBLIC RELATIONS}

Gender plays a significant role in both journalism and public relations. Women remain pigeon-holed in soft news in journalism and technician roles in public relations. Historically, women journalists were confined to pink ghettos (North 2014) writing stories about issues that traditionally concerned women, such as beauty, fashion and lifestyle. The gendered nature of journalism is evident from the traditional distinction between hard and soft news. Hard news has been defined as consisting of "factual presentations of events deemed newsworthy usually centring on serious stories about important topics including politics, economics, major crime/accidents and public interest matters" (North 2014, 1).

Hard news demands immediate publication. It is considered the most prestigious type of journalism and it is mostly undertaken by male reporters (Ross and Carter 2011, 1149). On the other hand, soft news does not demand immediate publication since it does not have "informational value" (van Zoonen 1998, 36); hence, it is usually prescribed to female reporters. Soft news "make readers laugh or cry, love or hate, envy or pity" (Bender et al. 2009, 134) which might be a reason why soft news is deemed less prestigious in the news hierarchy. This dichotomy is additionally stressed by Alcorn (2010) who states that "hard cock" stories are the good, penetrating stories, while "soft cock" stories are the girly stories that usually will not get published. Journalism remains "a maledominated profession immersed in the masculine culture of deciding what constitutes news" (Topić 2018, 434), even though its role, first and foremost, is to inform and educate (among other things) the citizenry. However, societal norms about femininity and masculinity still prevail where hard news is equated with masculine traits and is positioned at the top of the news hierarchy, whilst soft news is equated with feminine traits and is positioned lower in a news hierarchy.

Being predominantly hegemonically masculine, newsroom culture shapes the newspaper agenda. A parallel can be drawn with Bourdieu's (2007) masculine habitus in which women's work is impoverished and men's work maintains the superior value. However, the gender disparity in the allocation of stories has important ramifications than mere lack of equality in the newsroom. The notion of journalism acting as a watchdog of the public interest has long been advocated and if cultural hegemony still shapes the newspaper agenda the question remains - is journalism acting as a watchdog or as a mere lapdog?

Female and male journalists perceive journalism differently. This is in line with the radical feminist paradigm that argues that women fundamentally have different interests than men, and do things differently (Rakow \& Nastasia 2009; Maltz \& Borker 1982). They "consider different topics, angles, sources and ethics to be important. For example, the so-called "masculine" journalism focuses on politics, crime, finance, education and upbringing, while "feminine" journalism involves human interest, consumer news, culture and social policy" (Everbach and Flournoy, 2007, 53). It is a common knowledge that "journalism remains a masculine profession where standards of work such as newsgathering techniques and the way newsroom operate have not changed event with a significant arrival to women to journalism" (Topić 2020,7). However, from the perspective of public interest it was women 
who first "brought health and social affairs into the news, more human touches to writing, and also explanations about how news and other stories are relevant to readers" (Topić 2018, 436).

It is not only the female journalists who are facing gendered nature; it is also the female public relations professionals who are confined to the pink ghetto. Women in public relations are still subordinate to patriarchal ways of doing things (Yeomans 2019), and the findings of the EUPRERA "Women in Public Relations" project have shown that "the position of women in public relations has reached its full circle" (Topić et al. 2019, 6) since the 1980s when Velvet Ghetto (Cline et al. 1986), the first study on women in public relations, was published. In the 1980s, women in public relations were facing work discrimination (the glass ceiling, pay gap, women being confined to technician positions even though they were better educated) and bias (covert discrimination in promotions, chauvinism, stereotypes and decrease in prestige and wages due to feminization of public relations) and this unfavourable position surfaced between 2010 and 2019, with women once again reporting work discrimination (being confined to technician positions, the glass ceiling, pay gap, masculine work culture) and bias (stereotypes about organisational skills, lack of power, stereotypes about communication skills and intersectional discrimination) (Topić et al. 2019).

Gender stereotypes in journalism about women being more confined to cover soft news can be compared to gender stereotypes about women as "PR bunnies" (Fröhlich and Peters 2007) in the public relations industry, where women are often seen as "natural born communicators" which "(re)produces women's prescription to the technical role" (ibid, 2015) while men are ascribed to managerial roles. Communication skills advantage women entering the public relations field; however, when advancing their career, their communication skills are often viewed as a disadvantage since the picture of a manager is stereotypically connected with men and "masculine principle is posited as the measure of all things" (Bourdieu 2007, 14). Therefore, women in public relations have to embrace masculine-stereotyped patterns of on-the-job behaviour, what is commonly understood as cultural masculinity in behaviour to become part of masculine habitus (Bourdieu 2007; Alvesson 1998). This internalisation is supported by the "deeply embedded images of men as natural leaders and women as unsuitable for leadership" (Acker 2009, 214).

In addition to that, the parallel with the journalistic dichotomy of soft news being confined to women and hard news being confined to men can be traced as well in public relations where women feel more confined to the "traditional" areas of public relations like fashion or lifestyle because of long-standing stereotypes (Fröhlich and Peters 2007). Tracing back in history, L'Etang states that women in public relations were predominately recruited to work with fashion clients, and this was seen as "women's natural work" (L'Etang 2015). Women were largely in subordinate roles and restricted to the domestic economy and the gendered fields of beauty and fashion. The public relations occupational body "presented men as performers and women as decorative backstage labour, only allowed to perform in domesticated zones" (L'Etang 2015, 2915). Men were fronting the occupation while women were underpinning them with their "natural" skills such as interpersonal and communication skills, administrative and organisational skills. Therefore, it can be argued that topics of public interest are stereotypically confined to male public relations professionals which perpetuates Bourdieu's (2007) concept of male habitus where men continue to dominate the public space and the field of power. 


\section{CROATIA: The Position OF WOMEN In JOURNALISM AND PUBLIC RELATIONS}

When it comes to the position of women in Croatian journalism, two major gender issues arise - women are not visible enough in the media, and when they actually are visible, they are represented in a stereotypical manner (Dujmović 2020). According to the latest panel held by the Croatian Journalists Association and Trade Union of Croatian Journalists in 2020, women are underrepresented in the Croatian media in informative content, their achievements are insufficiently visible, their expertise does not enjoy equal treatment (mostly men are asked for an expert opinion on a topic). On the other hand, women are most represented in magazine content, mostly "packaged" in a stereotypical view. In only eight per cent of cases are women the protagonists of television news in Croatia. Female journalists are still not using gender-aware language calling themselves "novinar" (male journalist) instead of "novinarka" (female journalist). All this is particularly interesting to look at from the perspective of an occupation in which the majority of graduates are women (almost 70 per cent) (Dujmović 2020).

In addition to that, the journalism profession in Croatia has gone through a process of feminization, with the majority of journalism students now being female, but men still occupy more positions in the information and communication sector and are paid more for their work (Vozab and Zember 2016). Although, in general, the number of women and men in senior positions is similar, a deeper analysis discovers both hierarchical and sectoral segregation where "women occupy fewer positions in the management and decision-making level and more posts in areas that can be seen as an extension of their domestic responsibilities" (van Zoonen 2011, 50). Moreover, gender representation in the Croatian media is still not equal. According to Vozab and Zember (2016), the dominant cultural politics of re-traditionalisation and the retrograde domestication of women which took place in the 1990 s seem to have continued into the 2000s and now 2010s, mixing with the media's commercial logic.

When it comes to women in public relations in Croatia, the same patterns emerge. Men still occupy higher positions and are paid more for their work. Women in both journalism and public relations are facing the gendered-nature of the two industries. The latest and the first-ever report on the position of women in public relations in Croatia, conducted within EUPRERA project "Women in Public Relations", showed that the socalled masculine patterns still prevail in the public relations industry in Croatia (Polic and Holy 2020). The lived experiences of women working in the Croatian public relations industry are marked with long working hours, weighted work-life balance in which work increasingly dominates their private life and family, difficult and unequal career progression opportunities in comparison to male colleagues, conflicting expectations on women's behaviour and attitudes women need to demonstrate to progress, frequent examples of direct discrimination such as disapproval, different treatment based on gender, sexist comments and practices, and the impression that women need to behave differently to be taken seriously (Polić and Holy 2020). In addition to that, women have to be better than men to get approval.

All of these patterns suggest the prevalence of male habitus where Bourdieu stated that "the masculine principle is posited as the measure of all things" (Bourdieu 2007, 14). He constructed cultural masculinity through the notion of habitus by arguing that social norms are embedded in society through the socialisation process, which is fundamentally gendered (Bourdieu \& Wacquant 1992). Individuals do not challenge the usual order of 
things because the division between genders is deeply embedded in the social order. Thus, Bourdieu states that "we have embodied the historical structures of the masculine order in the form of unconscious schemes of perceptions and appreciation" (Bourdieu $2007,5)$ and this feeds into media portrayal and daily interactions because women fail to observe the mechanisms of domination due to them being deeply rooted in everyday practice (Topić 2020; 2020a).

\section{METHOD}

This paper used a qualitative research approach as it wanted to gain a deeper understanding of the portrayal of the \#MeToo movement in Croatian media outlets through the perspective of female public relations professionals. The research was conducted by the qualitative method of in-depth interviews which, due to the social distancing caused by the COVID-19 virus pandemic, were conducted by the Zoom Client for Meetings application. In-depth interviews were selected as a research method due to the lack of understanding and research on the selected topic. An interpretative approach was adopted for the investigation of the perceptions of Croatian female public relations professionals on portraying the \#MeToo movement in the Croatian media.

For the purpose of this research six female public relations professionals were recruited via personal contacts. Each interviewee was considered an expert if she had a managerial or teaching position. Two of the interviewees work in higher education and teach public relations, two are CEO's of their own public relations agencies and two hold public relations managerial roles in international companies. All interviewees work in Zagreb, the capital of Croatia, and thus the research is limited to the experiences of women in Zagreb. Interviewee demographics are presented in table 1 below.

Table 1 Interviewees' demographics

\begin{tabular}{cccc}
\hline Number & Type of an organization & Position & Sector \\
\hline 1 & Corporation & Head of Communication & Energy \\
2 & University & Teaching Assistant & Educational \\
3 & PR agency & CEO & Public relations \\
4 & Corporation & Head of Communication & Technology \\
5 & University & Professor & Educational \\
6 & PR agency & CEO & Public relations \\
\hline
\end{tabular}

The research objectives were as follows:

RO1): To research the perceptions of women in the Croatian public relations industry about the media portrayal on issues of public interest, especially those that are concerned with sexual discrimination and harassment.

RO2): To research the perceptions of women in the Croatian public relations industry about the portrayal of the \#MeToo movement in the Croatian media and its relationship with the gendered nature of newsrooms.

RO3: To research the perceptions of women in the Croatian public relations industry about the impact of the \#MeToo movement on the public relations industry and the activities that could have been done in raising the awareness regarding the topics concerned with sexual discrimination and harassment. 
The research questions were the following:

RQ1: How does the media in Croatia portray female sexual discrimination and harassment issues?

RO2: How did the media in Croatia portray the \#MeToo movement?

RO3: What was the impact of the \#MeToo movement on the public relations industry?

The questions were structured around perceptions of female public relations professionals in the following three areas - media portrayal of female sexual discrimination and harassment issues; media portrayal of the \#MeToo movement in Croatia and the impact of the \#MeToo movement on the public relations industry. What is central to all the questions is an exploration of masculine habitus (Bourdieu 2007), the concept of where men continue to dominate the public space and the field of power, throughout the portrayal of the \#MeToo movement in the Croatian media.

In the first group of questions, the existence of masculine habitus is conceptualised through questions on the portrayal of female sexual discrimination and harassment issues in the Croatian media with which I assessed whether the media give enough space to topics that are of public interest but related to women and whether media is fulfilling its role in reporting about them. Namely, journalists should be seeking the truth and fulfilling their obligation to report on topics of public interest. They should be gender-neutral acting as the "representatives of the general public" (Bailey, 2009, p. 300). However, journalism remains "a male-dominated profession immersed in the masculine culture on what constitutes the news" (Topić 2018, 434) even though its role first and foremost is to inform and educate the citizenry.

In the second group of questions, male habitus is conceptualised through questions on the relationship between the portrayal of the \#MeToo movement in the Croatian media and the gendered nature of newsrooms with which I assessed whether gender division, according to which hard news are male news and soft news are female news, as well as the editors' gender influenced the portrayal of the \#MeToo movement. The gendered nature of journalism is evident from the traditional distinction between hard and soft news, where hard news is the good, penetrating stories that get published while soft news is the girly stories that will usually not get published (Alcorn 2010). Societal norms about femininity and masculinity still prevail where hard news is equated with masculine traits and is positioned at the top of the news hierarchy, and soft news is equated with feminine traits and is positioned lower in the news hierarchy.

In the third group of questions, male habitus is conceptualised through questions on the changes that public relations professionals can make to ensure the greater visibility of female sexual discrimination and harassment issues in the media. Both female journalists and public relations professionals are confined to pink ghettos and they should develop good relationships to achieve stronger visibility of the issues that are stereotypically coloured as feminine ones. Although the public relations industry has suffered from a poor reputation and image since its earliest professionals paid little attention to ethics or social responsibility (Wright, 1979), public relations professionals can serve the public interest and should "encourage debate on issues of interest to the public" (Bivins 1993, 125), especially when it comes to female public relations professionals who should be aware of the similar position that female journalists share in the realm of gendered nature newsrooms. 
All interviews were transcribed for analysis and thematic analysis was used as the method. Thematic analysis is "a systematic approach to the analysis of qualitative data that involves identifying themes or patterns of cultural meaning; coding and classifying data, usually textual, according to themes; and interpreting the resulting thematic structures by seeking commonalities, relationships, overarching patterns, theoretical constructs, or explanatory principles" (Lapadat 2010, 926). The results are underpinned by the interviewees' direct quotes.

\section{FINDINGS AND DISCUSSION}

The analysis revealed three main themes that dominate the interviewee responses: the media's failed role in protecting the public interest, insufficient visibility of the \#MeToo movement in Croatian media and the lack of expertise in the media.

\subsection{Media's Failure to Protect the Public Interest}

Regarding the role that media in Croatia have in portraying the female sexual discrimination and harassment, the majority of interviewees concluded that the Croatian media have a "key" (Interviewee 2), "important" (Interviewee 3), "big" (Interviewee 4) and "strong" role in presenting those themes. Albeit the predominately strong attribution towards the responsibility of the Croatian media in portraying the themes of public interest, interviewees are sceptical regarding the media's fulfilment of it. For example,

"The media treat information like some kind of goods. They disregard the themes of public interest, while sensationalism prevails." (Interviewee 2) ${ }^{1}$

"Croatian journalism is torn between two waves that completely change the journalistic scene and put the news regarding female sex discrimination and harassment aside. The first wave is the race for clicks, which has killed journalistic analysis and professionalism and is slowly extinguishing the need for quality public information. The second wave is sublimated under the auspices of social networks. Due to the proliferation of social networks, everyone can become an analyst who knows everything about each topic. Social media in Croatia are flooded mostly with negative comments, especially when it comes to this sensitive topic." (Interviewee 3)

"The media neglect their role in portraying the themes of public interest especially when it comes to topics regarding the female sexual discrimination and harassment. The media turn to sensationalism. The Croatian media have forgotten their key role in informing and raising awareness and have unfortunately turned to the financial benefits they are trying to gain by transmitting news in a sensationalist way. Thus, instead of condemning the violence and conveying a strong message that violence of any kind is completely wrong, the Croatian media turn to the news in a way reminiscent of the yellow press and thus ensure greater readability and more discussions in comments on social networks that then bring them greater reach of their posts on social networks, and the public (accidentally or intentionally - I do not know) present the victim of violence as an immoral person who may have even caused and deserved the violence. Unfortunately,

\footnotetext{
${ }^{1}$ All of the interviewees' responses were translated by the author of the text.
} 
such a procedure discourages victims of violence and they choose not to report violence, in order to preserve their reputation and dignity." (Interviewee 6)

In addition to that, the media are not being gender neutral acting as the "representatives of the general public" (Bailey 2009, 300). Journalism remains "a male-dominated profession immersed in the masculine culture what constitutes the news" (Topić 2018, 434) even though its role, first and foremost, is to inform and educate the citizenry. For example,

"The Croatian media are even deepening and even go on deepening gender stereotypes.

This is especially evident in the portrayal of political and economic topics and so-called lifestyle topics. Male protagonists dominate in political and economic themes, while female protagonists dominate in lifestyle themes. Women are being stereotypically presented as the main protagonist of private rather than the public sphere. The so-called female topics are treated as less important than "serious", "male" topics." (Interviewee 5)

When it comes to the amount of space the Croatian media dedicate to themes that are concerned with female sexual discrimination and harassment, all of the interviewees agree that the Croatian media do not give enough space to those themes. In addition, they stated the different reasons to explain their unanimous point of view,

"The media are not interested in topics that deal with female sexual discrimination and harassment." (Interviewee 2 and 4)

"Media space is filled with news that hinders important news such as female sexual discrimination and harassments. In addition to that, victims are afraid to talk publicly about their experiences." (Interviewee 3)

"The media portray these themes only symbolically and occasionally (...) these topics are very rarely covered by men. It is some kind of rule that women deal with these topics and thus in this way we come to the vicious circle of women's ghettoization." (Interviewee 5)

According to van de Meer et al. (2016), acting as gatekeepers, journalists have the power to select the sources and the themes that will get a voice in media coverage. Themes of public interest, especially those dealing with female sexual discrimination and harassment should be a journalist's priority. However, one interviewee stated that not all blame shut be put on the media because acting as the gatekeeper, journalists often do not feel that the legal institutions will provide them with enough security.

"I think that the main culprit for this situation is probably the Croatian judiciary and the Ministry of the Interior. The media choose not to give coverage to sensitive topics because they do not feel safe and protected from the state. Media fears strict condemnation of the culprit. There are many non-profit organizations in our country that advocate for this topic, but the keyword in their name is "non-profit". It is these non-profit organizations that have a great desire to fight and raise awareness of the Croatian people - but for that, they have to pay for marketing space in the media." (Interviewee 6)

This additionally evokes Bivins' (2013) necessity for public relations professionals to "encourage debate on issues of interest to the public, and, where possible, offer representation when both sides of such issues are not adequately represented so as to foster informed public debate" $(2013,125)$. 


\subsection{Insufficient Visibility of the \#MeToo movement in Croatian media}

When it comes to the portrayal of the \#MeToo movement in the Croatian media, nearly all the interviewees stated that the Croatian media did not ensure enough visibility of the \#MeToo movement which goes in line with the opinions from the previous sections of the Croatian media not ensuring enough space for topics of public interest,

"When you look at the Croatian media, you might think that the \#MeToo movement has never happened." (Interviewee 2)

"Croatian society is still not sufficiently aware of how frequent cases of sexual violence and harassment are. In Croatia, one 'tweet' cannot change this situation, as it started an avalanche of women's confessions in the USA three years ago about women's experiences of sexual violence and harassment, and when about 200 men lost their positions of power." (Interviewee 3)

"You should ask my mom what the \#MeToo Movement is. She won't know. Victims of violence are not just young people who spend their days on Instagram. Victims of violence, discrimination and harassment are all around us and many of them do not even have a mobile phone, and they look at social networks as quantum physics. The Croatian media did not give enough space, not only to this movement but to any movement that would change the consciousness of the people regarding the victims of any form of violence." (Interviewee 5)

However, one interviewee echoed that there was a difference in the media's portrayal of the \#MeToo movement according to the phases of the movement:

"At first they did, but it only lasted while the topic was "in trend". My impression is that even then the \#MeToo movement was represented in a frivolous or spectacular way. Narratives related to famous people from the so-called red-carpet sphere and the treatment of the theme itself was often caricatured, so women's demands were portrayed in a somewhat grotesque context so the mainstream society flows could distance themselves from the \#MeToo movement, considering it as something aggressive and exaggerated. And yes, that was completely intentional." (Interviewee 5)

When it comes to the relationship between the portrayal and gendered nature of newsrooms, the majority of interviewees deem a relationship exists between the portrayal of the \#MeToo movement and the gendered nature of the newsroom based on the gendered orientation of editors and editors in chiefs.

"The majority of editors and editors in chief are male. Men are not interested in these kinds of topics." (Interviewee 1)

"The fact that in most Croatian mainstream mass media men are in management positions speaks for itself." (Interviewee 5)

However, those who do not agree with the gendered nature of newsrooms affecting the visibility of the \#MeToo movement in the Croatian media explained that it is due to the "paid content that is more important than the themes of public interest" (Interviewee 3) and "the existence general (regardless of gender and function) disinterest of people regarding the problems that do not affect them and the belief that their intervention will not change anything about the Croatian judiciary and the state's attitude towards the powerful people those that media like to call controversial entrepreneurs" (Interviewee 6). 
Interviewees also supported the relationship between the gendered division of hard (male) and soft (female) news and the portrayal of the \#MeToo movement in the Croatian media:

"Men get the chance to present the breaking news, while women are convicted to fashion and lifestyle themes." (Interviewees 1 and 4)

"A couple of years ago, I researched this very topic and conducted in-depth interviews with five influential Croatian political journalists from national dailies. The research showed that journalists in Croatia are aware of gender inequalities in Croatian society, politics and the media. However, when it comes to their own sense of responsibility for gender-stereotypical media coverage of women politicians, most respondents do not feel responsible for it. They shift the responsibility to the lifestyle newspaper sections and female politicians (...) which indicates the presence of patriarchal dogmas in the researched journalists. Also, the female journalists claim that women in Croatia do not have the same chances for success as men, especially in politics, but they accept the patriarchal dogma that women do not belong to the public, but a private sphere. This is evident from their claims that the small number of women in politics is the result of women's lack of interest in politics, rather than the social climate that represents women in politics as masculine, less female." (Interviewee 5)

However, it is interesting to note that one interviewee, who worked as a journalist, stated that such a gendered division between hard and soft topics does not exist, saying that "I have been working as a journalist and I have never seen this kind of gendered division" (Interviewee 3). The majority of the interviewees think that the relationship between the gender of editors and editors in chief is more relevant for the explanation of the low visibility of the \#MeToo movement rather than the journalistic dichotomy of soft news being confined to women and hard news being confined to men. Therefore, Croatian media outlets can be related to Bourdieu's (2007) masculine habitus in which women's work is impoverished, and men's maintains the superior value. If cultural hegemony shapes decisions on which stories will get media coverage, it the question of whether journalism is a watchdog or a mere lapdog still stands.

\subsection{Lack of Expertise in the Media}

When it comes to the activities that the Croatian media could have done to enhance the visibility of the \#MeToo movement, half of the interviewees stated that media do not foster relationships with experts when covering sensitive topics such as the \#MeToo movement is, and that there should have been "more examples of this kind of cases in Croatia" (Interviewee 1), "a stronger synergy and cooperation between the organizations for the protection and promotion of human rights is needed, including the Ombudsman and specialized ombudsmen, non-governmental organizations and media is needed. This cooperation would provide the media with professional, more frequent and detailed information on cases related to sexual discrimination" (Interviewee 2) and "Journalists could write more about this topic through professional articles with competent interlocutors and report on such cases in Croatia" (Interviewee 3). 
These views echo the journalistic need for a competent source of information as well as the fact that professionals are one of the sources that a journalist can use when covering a story. Where the public relations source is credible, there should be less suspicion of the relationship with the journalist (Bailey 2009).

According to all the interviewees, the \#MeToo movement did not cause any changes in the public relations industry or them personally. However, two interviewees emphasized the still prevailing pink ghettos that women are being confined to in the public relations industry and in general:

"Statistically, there are more women in the public relations industry compared to men, but in order to progress, they must develop managerial skills, be more confident and ambitious to break the glass ceiling. Although women in the PR industry often face gender discrimination, I believe that this movement has not caused a change in the PR industry in the Republic of Croatia." (Interviewee 2)

"We still have gender stereotyping, a small number of women politicians and socially active women in the most-watched political shows, politics and the economy are still dominated by men and lifestyle content by women. The problems of gender equality and gender stereotyping of women are often caricatured, with abundant use of spin techniques by which feminists are portrayed as, to illustrate, unattractive, loud, moustachioed blokish women, lesbians or frustrated faggots. The majority of society applauds such narratives thus closing the circle again. And women are afraid to expose and declare themselves as feminists so as not to accidentally get such an unattractive and unfeminine label." (Interviewee 5)

Interviewees also shared their insights on how topics such as the \#MeToo movement could become more visible in the Croatian media. The majority of the answers showed that a patriarchal system which perpetuates gender expectations and stereotypes still prevails in Croatia. Croatian society supports the deeply embedded images of men as a measurement for everything which can be linked to Acker's assertion about the "deeply embedded images of men as natural leaders and women as unsuitable for leadership" (Acker 2009, 214).

"Women should speak publicly on these topics more often and they should not be embarrassed because of it." (Interviewee 1)

"Although the \#MeToo movement did not have an impact on me, this movement is certainly an excellent example of how to further raise awareness, sensitize, animate and educate society in the Republic of Croatia about sexual violence and harassment. Also, I think that the \#SpasiMe movement in Croatia, which consequently followed the public speech of MP Ivana Ninčević-Lesandrić about her own experience of curettage without anaesthesia, is a good example of activism to combat sex discrimination. In addition to the above mentioned, I believe that it is crucial that state institutions make great efforts and solutions in combating gender discrimination. Croatia needs a coherent system that will work in a timely manner and protect the dignity of the victim". (Interviewee 2)

"The whole patriarchal system that reproduces stereotypes must be challenged." (Interviewee 4) 
"I advocate the strengthening of radical variants of feminism. We need to work much more on educating and raising awareness of women because women are still in most cases raising children, both daughters and sons, and they should be made aware that they should not be raised for defined gender roles. Besides, with the widespread dogma of female passivity, women still think that power is given, that they will get it from men. No, why would men give them power? Power is never given, power is always taken, and that means we women need to care about who is talking and thinking, we need to work together and stay focused on our goal, and that is gender equality in a political, economic, legal, social and psychological sense." (Interviewee 5)

In addition to that, public relations activities can in a significant way help media in fulfilling their role as a watchdog which goes against the critique that "all public relations is evil and works against the public good" (Brunner and Smallwood 2019, 3) which is also echoed in the interviewees' point of view,

"We need more public relations campaigns that will sensitize the public about sexual violence, encouraging them to report violence whether they are a victim or a person close to them, a witness or asking for help." (Interviewee 3)

"I admire people who did not give up and they are ready to fight for their rights. I am waiting for something as the \#MeToo movement to happen in Croatia. There should be more campaigns like this." (Interviewee 6)

Public relations professionals know that public interest is the central tenet in implementing public relations activities which is additionally echoed by the interviewees who stated that there should be more campaigns that will sensitize people regarding sensitive topics.

\section{CONCLUSION}

According to the views echoed by six public relations professionals, the Croatian media did not give enough space to the portrayal of the \#MeToo movement, nor does it give enough space to the portrayal of topics of public interest concerning the female sexual discrimination and harassment. The majority of interviewees, however, stated that the media have a strong and key role in presenting those topics to the citizens.

The reasons for this could be traced to the gendered orientation of editors and editors in chief. Since men still predominantly hold managerial positions in Croatian newsroom, topics such as the \#MeToo movement will not get enough visibility. In addition to that, the majority of interviewees think that the relationship between the gender of editors and editors in chief is more relevant for the explanation of low visibility of the \#MeToo movement rather than the journalistic dichotomy of soft news being confined to women and hard news being confined to men. Therefore, Croatian media outlets can be related to Bourdieu's (2007) masculine habitus in which women's work is impoverished and men's maintains the superior value.

According to van de Meer et al. (2016), acting as gatekeepers, journalists have the power to select the sources and the themes that will get a voice in media coverage. Themes of public interest, especially those dealing with female sexual discrimination and harassment should be a journalist's priority. However, according to the interviewees' point of view, the Croatian media are not fulfilling their role of portraying these themes 
and giving them appropriate space. This additionally evokes Bivins' (2013) necessity for public relations professionals to "encourage debate on issues of interest to the public, and, where possible, offer representation when both sides of such issues are not adequately represented so as to foster informed public debate" (Bivins 2013, 125). Public relations activities can in a significant way help the media in fulfilling their role as a watchdog which goes against the critique that "all public relations is evil and works against the public good" (Brunner and Smallwood 2019, 3).

Public relations professionals know that public interest is the central tenet in implementing public relations activities, which is additionally echoed by the interviewees who stated that there should be more campaigns that will sensitize people regarding sensitive topics. This is especially true in the Croatian context due to the fact that the majority of interviewees still describe Croatian society as a patriarchal one which perpetuates gender expectations and stereotypes. If cultural hegemony shapes the overall society and the editors' decisions on which stories will get media coverage, the question of whether Croatian journalism is a watchdog or a mere lapdog still remains open.

\section{REFERENCES}

Acker, J. "From Glass Ceiling to Inequality Regimes". Sociologie du travail 51, 2 (2009): 199-217.

Alcorn, G. "Feminism has Failed. Debate (Video Recording)". The Wheeler Centre, Melbourne, September, 22, 2010. Retrieved from: https://www.youtube.com/watch?v=XiQVv7y6bKM

Bailey, R. "Media Relations". In Exploring Public Relations, 2th ed., edited by Tench. R. and L.Yeomans, 295314. Harlow and England: Pearson Education, 2009.

Bender, J. R. et al. Reporting for the Media, 9th ed. New York: Oxford University Press, 2009.

Bivins, T. H. "Public Relations, Professionalism, and the Public Interest". Journal of Business Ethics 12, 2 (1993): $117-126$.

Bourdieu, P. Masculine Domination. Cambridge: Polity Press, 2007.

Brunner, B. R. and A. M. K. Smallwood. "Prioritizing Public Interest in Public Relations: Public Interest Relations". Public Relations Inquiry 8, 3 (2019): 1-20.

Cline, C. et al. The Velvet Ghetto: The Impact of the Increasing Percentage of Women in Public Relations and Business Communication. USA: IABC Foundation, 1986.

Dujmović, A. "Ravnopravnost spolova u hrvatskim medijima [Newspaper article]". Žene i mediji, 2020. Retrieved from: https://www.zeneimediji.hr/ravnopravnost-spolova-u-hrvatskim-medijima/

Everbach, T. and C. Flournoy. "Women Leave Journalism For Better Pay, Work Conditions". Newspaper Research Journal 28, 3 (2007): 52-64.

Fröhlich, R. and S. B. Peters. "PR Bunnies Caught in the Agency Ghetto? Gender Stereotypes, Organizational Factors, and Women's Careers in PR Agencies". Journal of Public Relations Research 19, 3 (2007): $229-254$.

Gill, R. and S. Orgad. "The Shifting Terrain of Sex and Power: From the 'Sexualization of Culture' to \#MeToo". Sexualities 0 (2018): 1-12.

Gersen, C. "Tagging onto \#MeToo [Blog post]". Masters of Media, 2017. Retrieved from: https://mastersofmedia. hum.uva.nl/blog/2017/11/16/taggingonto-metoo

Grunig, J. E. and T. Hunt. Managing Public Relations. New York: Holt, Rinehart \& Winston, 1984.

Halff, G. and A. Gregory. "What is Public Relations to Society? Toward an Economically Informed Understanding of Public Relations\#. Public Relations Review 41, 5 (2015): 719-725.

Hanitzsch, T. "Journalists as Peacekeeping Force? Peace Journalism and Mass Communication Theory". Journalism Studies 5, 4 (2004): 483-495.

Ihlen, O. and P. Verhoeven. “A Public Relations Identity for the 2010s”. Public Relations Inquiry 1, 2 (2012): 159-176.

Kunac, S. and S. Sarnavka. „Ženska“ percepcija medijskih sadržaja. Zagreb: B.a.B.e!, 2006. 
L'Etang, J. "It's Always been a Sexless Trade"; "It's Clean Work"; “There's very Little Velvet Curtain”. Journal of Communication Management 19, 4 (2015): 354-370.

North, L. "The Gender of 'Soft' and 'Hard' News Female Journalists' Views on Gendered Story Allocations". Journalism Studies 17, 3 (2014): 356-373.

Polić, M. and M. Holy. Women in Public Relations in Croatia. EUPRERA Report Vol 1, No. 2. Leeds/Brussels: Creative Media and Communications Research Ltd \& EUPRERA, 2020. Retrieved from: http://eprints. leedsbeckett.ac.uk/id/eprint/7016/1/WomenInPublicRelationsInCroatiaPV-TOPIC.pdf

Rakow, L. F., and D. I. Nastasia. "Feminist Theory of Public Relations: An Example from Dorothy E. Smith". In Public Relations and Social Theory, edited by I. Oyvind, B. van Ruler, and M. Frederiksoon, 252-277. London: Routledge, 2009.

Ross, K. and C. Carter. "Women and News: A Long and Winding Road". Media, Culture \& Society 33, 8 (2011): 1148-1165.

Saad, N. "Harvey Weinstein's Accusers: List Includes Fledgling Actresses and Hollywood Royalty. [Newspaper article]". New York Times, 2018. Retrieved from: https://www.latimes.com/entertainment/la-et-weinsteinaccusers-list-20171011-htmlstory.html

Starkey, J. et al. “\#MeToo Goes Global: Media Framing of Silence Breakers in Four National Settings”. Journal of Communication Inquiry 43, 4 (2019): 437-461.

Stoker, K. and M. Stoker. "The Paradox of Public Interest: How Serving Individual Superior Interests Fulfill Public Relations' Obligation to the Public Interest”. Journal of Mass Media Ethics 27, 1 (2012): 3-45.

Tomić, Z. Odnosi s javnošću: teorija i praksa. Zagreb i Sarajevo: Synopsis, 2016.

Tomić-Koludrović, I. and M. Petrić. "Identities on the Net: Gender and National Stereotypes on Croatian Broadreach Portals". Društvena istraživanja 13, 4-5 (2003): 803-823.

Topić, M. "Not Bloke-ified Enough? Women Journalists, Supermarket Industry and the Debate on Sugar in the British Press (2010-2015)". Newspaper Research Journal 39, 4 (2018): 433-442.

Topić, M. et al. Women in Public Relations - A Literature review (1982-2019). EUPRERA Report Vol. 1, No. 1. Leeds/Brussels: Creative Media and Communications Research Ltd. \& EUPRERA, 2019. Retrieved from: http://eprints.leedsbeckett.ac.uk/id/eprint/6138/12/EupreraReportPV-TOPIC.pdf

Topić, M. Women in Public Relations in England. EUPRERA Report, Vol. 1, No. 2. Leeds/Brussels: Creative Media and Communications Research Ltd \& EUPRERA, 2020. Retrieved from: http://eprints.leedsbeckett. ac.uk/6774/1/EUPRERAReportVol1No2PV-TOPIC.pdf

Topić, M. "Two Englands? Blokishness, Masculine Habitus and the North-South Divide in the Advertising Industry". Gender in Management: An International Journal, 2020a. Retrieved from: https://www.emerald. com/insight/content/doi/10.1108/GM-12-2019-0263/full/html

van der Meer, T. G. L. A. et al. "Disrupting Gatekeeping Practices: Journalists' Source Selection in Times of Crisis". Journalism 18, 9 (2017): 1107-1124.

van Zoonen, L. "One of the Girls? The Changing Gender of Journalism". In News Gender and Power, edited by C. Carter, G. Branston, and S. Allan, 33-46. London: Routledge, 1998

Veil, S.R. "Clearing the Air: Journalists and Emergency Managers Discuss Disaster Response". Journal of Applied Communication Research 40, 3 (2012): 289-306.

Vozab, D., and A. Zember. "Croatia: Does Equality in Representation Lead to Equality in Content? In Women in media industries in Europe (ECREA book series), edited by K. Ross, and C. Padovani, 72-82. New York and London: Routledge, 2016.

Wright, D. K. "Professionalism and Social Responsibility in Public Relations". Public Relations Review 5 (1979): 20-33.

Yeomans, L. "Is a 'New Feminist Visibility' Emerging in the UK PR Industry? Senior Women's Discourse and Performativity within the Neoliberal PR Firm". Public Relations Inquiry 8, 2 (2019): 127-147.

Zacharek, S., E. Dockterman, and H. Sweetland Edwards. "The Silence Breakers. [Newspaper article]". Time, 2017. Retrieved from: https://time.com/time-person-of-the-year-2017-silence-breakers/. 


\section{PERCEPCIJE ŽENA U ODNOSIMA S JAVNOŠĆU O PORTRETU \#METOO POKRETA U HRVATSKIM MEDIJIMA}

\#MeToo pokret je postigao značajan status 2017. godine kada je \#MeToo hashtag postao viralnim i osvestio celi svet o nivou problema seksualnoga nasilja. Glumica Alisa Milano napisala je prvi tweet u kome je optužila producenta Harvija Vajnštajna za seksualni napad. S obzirom da su istraživanja o problemu \#MeToo pokreta u različitim kulturnim kontekstima ograničena i postojeća istraživanja se uglavnom svode na zapadne percepcije, ovaj rad istražuje percepcije šest stručnjakinja za odnose s javnošć o portretisanju \#MeToo pokreta u hrvatskim medijima. Tematska analiza je sprovedena na podacima iz realizovanih intervjua. Rezultati pokazuju da tri teme dominiraju u odgovorima intervjuisanih stručnjakinja: nesposobnost medija da zaštite javni interes, nedovoljnu vidljivost \#MeToo pokreta u hrvatskim medijima, te nedostatak stručnosti u medijima.

Ključne reči: Hrvatska, \#MeToo pokret, odnosi s javnošću, novinarstvo, seksualna diskriminacija. 